\title{
Ellipsis
}

2017

\section{Scratch and How to Survive the Heat}

\author{
Betsy Housten \\ University of New Orleans
}

Follow this and additional works at: https://scholarworks.uno.edu/ellipsis

\section{Recommended Citation}

Housten, Betsy (2017) "Scratch and How to Survive the Heat," Ellipsis: Vol. 44 , Article 4.

DOI: https://doi.org/10.46428/ejail.44.04

Available at: https://scholarworks.uno.edu/ellipsis/vol44/iss1/4

This Poetry is brought to you for free and open access by the Department of English and Foreign Languages at ScholarWorks@UNO. It has been accepted for inclusion in Ellipsis by an authorized editor of ScholarWorks@UNO.

For more information, please contact scholarworks@uno.edu. 


\section{Scratch}

Betsy Housten

My friend and I sit in a café and talk about bread.

He is a baker; he tells me about leaving California for a small town in Maine, learning to rotate the pans in the old-fashioned oven, the rye he wasted following someone else's recipe.

Later, I meet you for dinner. There is a band on your finger-not an engagement, you correct me, a promise ring. I tease you about sounding like a teenager. It is my only defense.

I will not admit I am no longer hungry.

I look at your face, the smile I gave up trying not to miss, your mouth with its new lines, the flush on your cheeks as you speak of her. I lift my glass, not trusting my voice. Your eyes are kind. I cannot bear it; I am longing

for that other table, to hear again about his little bakery, how he opens the door and starts over from nothing every day, hours before dawn, hands deep in dough, shaping each loaf like a prayer. 


\section{How to Survive the Heat}

Betsy Housten

An hour after I meet her, she offers to show me the two-step. There's nothing to it, she says.

Would you like to try? Limbs slick with sweat, I am uncertain, but I stand anyway, because this

is why I have come. To take chances. She reaches for my hand, guides me to a dark corner of the bar.

Don't worry. We'll stay back here. Sliding her fingers from my shoulder to my wrist, she spins me in tight

to embrace me from behind. Suddenly my knees are everywhere, colliding with hers, angling too wide over feet that will not understand where to land. I am clumsy, erratic; I do not know how to be led.

The bordello red of the marquee paints her dress a blazing violet. Afterward we discover we loved the same girl at different times, step outside to call her together, leave a message when she does not pick up.

Feline steam climbs the streetlights, shimmering puddles drip into drains. When I admit I come

from a city of blizzards, she puts her mouth to my ear, whispers a trick to stay cool through summer

in the south: Ice cubes in a bucket. Jump right in. It's magic. Her face is so close, her body all valleys

and swells. The August air thickens with each hot breath, unmapped steps, all the new secrets. 